\title{
Cumulative Contents
}

Editorial

Sperm quality assessed by flow cytometry and accessory sex gland function in

spinal cord injured men after repeated vibration-induced ejaculation

E Engh, O P F Clausen, K Purvis, $R$ Stien

Skin potential recordings during cystometry in spinal cord injured patients

$J$ G Prévinaire, $J$ M Soler, $P$ Hanson

The chances of a spina bifida patient becoming continent/socially dry by

conservative therapy

M Knoll, H Madersbacher

Ambulation in patients with myelomeningocele: a study of 1500 patients

I Díaz Llopis, M Bea Muñoz, E Martinez Agulló, A López Martinez,

$V$ García Aymerich, $J$ V Forner Valero

Length-tension relationship of the posterior deltoid to triceps transfer in C6

tetraplegic patients

E Rabischong, P Benoit, M Benichou, Y Allieu

Sonographic diagnosis of heterotopic bone formation in spinal injury patients

$V N$ Cassar-Pullicino, M McClelland, D A H Badwan, I W McCall,

$R$ G Pringle, $W$ El Masry

Neurovascular complications of heterotopic ossification following spinal cord injury

$S C$ Colachis, $D$ M Clinchot, D Venesy

Conservative treatment of burst fractures of the thoracolumbar and lumbar

spine

H Kinoshita, Y Nagata, H Ueda, K Kishi

Spinal cord injuries in Iceland 1973-1989. A follow up study

$S$ Knútsdóttir

Letter

Meetings and Notices

A review of some measurements of muscle wasting, tone and clonus in

paraplegia

E G Walsh

Spinal shock: possible role of receptor plasticity and non synaptic transmission

$P$ Bach-y-Rita, L S Illis

Rehabilitation of spinal cord injured patients on long term ventilation

J C Chawla

The impact of home based ventilator dependence on family life

$C$ A Glass

The lack of comprehensive care causing complications in patients with myelodysplasia

$G$ Exner, $H$ Burgdörfer, A Bohatyrewicz, $G$ Bomnüter, $B$ Wenck

$28 \mathrm{~K}$ in squamous metaplasia of the bladder in patients with spinal cord injury

$J$ Z Montgomerie, HJ Holshuh, A J Keyser, CJ Bennett, D G Schick

The physiological benefits of paraplegic orthotically aided walking

C Ogilvie, P Bowker, D I Rowley

A new double-purpose device for elbow extension in tetraplegia with paralysis below C5

M Itzkovich, A Catz, I Ona

A complicated trochanteric pressure sore: what is the best surgical 
Effects of cisapride on anorectal and vesicourethral function in spinal cord 125

injured patients

$R$ Carone, D Vercelli, P Bertapelle

Spinal cysticercosis. Case report and review

A Isidro-Llorens, F Dachs, J Vidal, M Sarrias

Late-onset papilledema following spinal injury. Case report

A Catz, I Appel, I Reider-Grosswasser, Z Grosswasser, L Mendelson,

$R$ Gepstein

Book Reviews

IMSOP Information Co-ordinators 139

Meetings and Notices $\quad 140$

$\begin{array}{ll}\text { Editorial } & 141\end{array}$

Tetraplegics and the justice of resource allocation 143

$P$ Walsh

The French organisation of mechanical ventilation at home for neuromuscular

diseases

P Gajdos

Experience with ventilator dependent patients

150

$R$ E Carter

Southport experience with domiciliary ventilation

$J$ D Bingley

The Swedish experience in the organisation of domiciliary ventilation for

patients with a high spinal cord injury

$R$ Harlid, $G$ Andersson

Implications of focal spinal cord lesions following trauma: evaluation with

magnetic resonance imaging

$M$ Silberstein, O Hennessy

The development of a spinal injuries unit in Armenia

$D C$ Burke, D Brown, $V$ Hill, $K$ Balian, A Araratian, $C$ Vartanian

Arterial oxygen saturation over time and sleep studies in quadriplegic patients

$C$ Cahan, $B$ Gothe, M J Decker, J L Arnold, K P Strohl

The dynamics of magnetic resonance findings in patients with a spinal

haematoma

$R$ Firsching, $F$ Zanella, $H$ Lanfermann

Pyrexia in hospitalised spinal cord injury patients

$P S S$ Beraldo, E G C Neves, C M F Alves, $P$ Khan, A C M Cirilo,

$M R$ B Alencar

Neurological outcome from conservative or surgical treatment of cervical

spinal cord injured patients

$J$ E Kiwerski

Meetings and Notices

Developments in the health service: the role of the Department of Health

$N$ P Halliday

The Swedish modification of the tracheostomy tube to permit speech

$G$ Andersson

The role of functional electrical stimulation in the rehabilitation of patients

with incomplete spinal cord injury - observed benefits during gait studies

$M H$ Granat, A C B Ferguson, B J Andrews, $M$ Delargy

Preclinical trial of 4-aminopyridine in patients with chronic spinal cord injury

$K C$ Hayes, A R Blight, P J Potter, R D Allatt, J T C Hsieh, D L Wolfe,

$S$ Lam, J T Hamilton

Assessing selfcare status in quadriplegia: comparison of the quadriplegia index of functions (QIF) and the functional independence measure (FIM) 
$R J$ Marino, $M$ Huang, P Knight, G J Herbison, J F Ditunno, M Segal

Blockage of indwelling urinary catheters: the roles of urinary composition, the catheter, medication and diet

$R$ G Burr, I Nuseibeh

Continent urinary diversion and diverting colostomy in the therapy of

non-healing pressure sores in paraplegic patients

$D E$ Bejany, $R$ Chao, $P$ E Perito, $V$ A Politano

Clinical aspects of neurolathyrism in Unnao, India

$U K$ Misra, $V P$ Sharma, $V P$ Singh

Physical performance of elite wheelchair basketball players in armcranking

ergometry and in selected wheeling tasks

YHutzler

Cervical spinal cord atrophy associated with spina bifida

A Seichi, Y Hoshino, S Ikegawa, T Tanaka, Y Yanagisako, M Kimitsuka,

T Kurokawa

Serum rheumatoid factors in spinal cord injury patients

$N V$ Petrova, A M Ponomaryova, $V$ A Alyoshkin, A T Eliseyev,

$G S$ Yumashev

Obituary

A Gordon Kev

Meetings and Notices

Editorial

Recommendations concerning the costing and management for patients

requiring domiciliary ventilation

K R Krishnan

Assistive technology in the rehabilitation of patients with high spinal cord

lesions

$R G S$ Platts, $M$ H Fraser

Clean intermittent catheterisation - performing abilities, aversive experiences and distress

A Bakke, L M Irgens, U F Malt, P A Høisater

Teaching the procedure of clean intermittent catheterisation

$S$ Parmar, S Baltej, S Vaidyanathan

Limb blood flow, cardiac output and quadriceps muscle bulk following spinal

cord injury and the effect of training for the Odstock functional electrical

stimulation standing system

P N Taylor, D J Ewins, B Fox, D Grundy, I D Swain

Effect of high voltage pulsed galvanic stimulation on sacral transcutaneous

oxygen tension levels in the spinal cord injured

A R Mawson, F H Siddiqni, B J Connolly, C J Sharp, $G W$ Stewart,

W R Summer, J J Biundo

The morbidity due to lower urinary tract function in spinal cord injury

patients

P E V Van Kerrebroeck, E L Koldewijn, S Scherpenhuizen, F M J Debruyne

Pediatric wheelchair athletics: sports injuries and prevention

$P E$ Wilson, $R$ L Washington

Magnetic resonance imaging in the diagnosis of spinal hydatid cyst disease.

Case report

A Fahir Özer, M Memet Özek, M Necmettin Pamir, C Erzen

Book Reviews

Meetings and Notices

Anxiety and depression over the first year of spinal cord injury: a longitudinal study 
$K M$ Hancock, A R Craig, H G Dickson, E Chang, J Martin

Outcome after vertebral fractures with neurological lesion treated either surgically or conservatively in Spain

P Bravo, C Labarta, M A Alcaraz, J Mendoza, A Verdu

Factors related to the outcome of inpatient rehabilitation in patients with

neoplastic epidural spinal cord compression

$H G$ A Hacking, H H J Van, G J Lankhorst

Achondroplasia and spinal cord lesion. Three case reports

$N$ Hamamci, S Hawran, F Biering-Sørensen

Clean intermittent catheterisation for the neuropathic bladder

A Yadav, S Vaidyanathan, D Panigrahi

Esophagitis and esophageal motor abnormalities in patients with chronic

spinal cord injuries

J G Stinneford, A Keshavarzian, B A Nemchausky, M I Doria, M Durkin

Colonic volvulus in the spinal cord injured patient

$D$ Fenton-Lee, $B W$ Yeo, $R$ F Jones, $S$ Engel

Traumatic spinal cord injuries in the rural region of Taiwan: an

epidemiological study in Hualien county, 1986-1990

$C$ Lan, J S Lai, K H Chang, Y C Jean, I N Lien

Pulmonary obstruction in individuals with cervical spinal cord lesions

unmasked by bronchodilator administration

A M Spungen, $P V$ Dicpinigaitis, $P$ L Almenoff, $W$ A Bauman

Hereditary spastic paraplegia associated with epilepsy, mental retardation and

hearing impairment

J S Yih, S-J Wang, M-S Su, S-C Tsai, R-H Lin, K-N Lin, H-C Liu

Giant-cell tumour of the lumbar spine. Case report

$S$ Inci, A Akbay, $V$ Bertan

Letter

Meetings and Notices

Methylprednisolone treatment of experimental spinal cord injury

A Iwai, $W W$ Monafo, $S$ G Eliasson

Inappropriate weaning and late onset ventilatory failure of individuals with

traumatic spinal cord injury

$J$ R Bach

Report on a conference on motor prostheses for workplace mobility of

paraplegic patients in North America

$C$ Kantor, B J Andrews, E B Marsolais, M Solomonow, $R D$ Lew,

KT Ragnarsson

The Functional Independence Measure: a comparative study of clinician and

self ratings

N Grey, P Kennedy

Meal-induced rise in resting energy expenditure in patients with complete

cervical spinal cord lesions

A-K Aksnes, T Brundin, $N$ Hjeltnes, $S$ Maehlum, J Wahren

Haemoglobin and albumin as predictors of length of stay of spinal injured

patients in a rehabilitation centre

$R$ G Burr, L Clift-Peace, I Nuseibeh

Sacrococcygeal hydatid cyst: another entity in the differential diagnosis of

sacrococcygeal chordoma. Case report

$C$ Yegen, A F Ozer, A O Aktan, $R$ Yalin

Obituary

Jack Walsh

Meetings and Notices 
Two-point discrimination thresholds in spinal cord injured patients with dysesthetic pain

$Z K$ Song, M J Cohen, P A Ament, W H Ho, MVulpe, S L Schandler

Bacterial biofilm formation on the bladder epithelium of spinal cord injured

patients. II. Toxic outcome on cell viability

$G$ Reid, Y S Kang, $M$ Lacerte, $C$ Tieszer, $K C$ Hayes

Ultrasound in the early diagnosis of heterotopic ossification in patients with spinal injuries

$R$ Bodley, A Jamous, D Short

The association between deep venous thrombosis and heterotopic ossification in patients with acute traumatic spinal cord injury

$S$ C Colachis, D M Clinchot

Indomethacin and disodium etidronate for the prevention of recurrence of heterotopic ossification after surgical resection. Two case reports

F Biering-Sфrensen, E Tøndevold

Intrathecal baclofen: does tolerance occur?

$M N$ Akman, $P$ G Loubser, W H Donovan, M E O'Neill, C D Rossi

Red Cross spinal injury project in Bucharest, Romania

A Soopramanien

The causes, sequelae and attempts at prevention of cervical spine injuries in

Poland

J E Kiwerski

Electrical stimulation-assisted rowing exercise in spinal cord injured people.

A pilot study

JJ Laskin, E A Ashley, L M Olenik, R Burnham, D C Cumming,

$R D$ Steadward, G D Wheeler

Complete dislocation with burst fracture of the lower cervical spine.

Case report

$S$ Bhatia, B S Sharma, SN Mathuriya, A Pathak, V K Khosla

Obituary

Dr Erik Moberg

Book Reviews

Meetings and Notices

Pathology of cervical intervertebral disc injuries

H Kinoshita

Prediction of pulmonary function in wheelchair users

$R$ A Cooper, F D Baldini, W E Langbein, $R$ N Robertson, P Bennett,

$S$ Monical

Risk of cardiac dysrhythmias in chronic spinal cord injury patients

$D$ A Leaf, $R$ A Bahl, $R H$ Adkins

Trophic effects on testes in paraplegics

$P$ A Chapelle, A Roby-Brami, M Jondet, T Piechaud, B Bussel

Prediction of maximal aerobic power from a submaximal exercise test

performed by paraplegics on a wheelchair ergometer

$G$ Paré, L Noreau, C Simard

Evidence of autonomic dysreflexia during functional electrical stimulation in

individuals with spinal cord injuries

E A Ashley, J J Laskin, L M Olenik, R Burnham, $R$ D Steadward,

$D C$ Cumming, $G D$ Wheeler

Deep vein thrombosis in spinal cord injured patients

Ş Gündüz, E Oğur, H Möhür, İ Somuncu, E Açjksöz, B Üstünsöz

Errors and limitations of the multimodality checking methods of defective

spinal intrathecal pump systems. Case report 
B Schurch

Carcinoma of the scrotum associated with rubber urinals. Case report

D Grundy, A C Jones, P H Powley

Retirement of Mrs Ann Scott MA: editorial secretary

Meetings and Notices

Editorial

Interinstitutional agreement of individual functional independence measure

(FIM) items measured at two sites on one sample of SCI patients

$M$ E Segal, J F Ditunno, W E Staas

Social support and health status in spinal cord injury

$C$ A Anson, D J Stanwyck, J S Krause

Methicillin-resistant Staphylococcus aureus (MRSA) colonization in patients with spinal cord injury

$K$ Maeder, $V J$ Ginunas, J Z Montgomerie, H N Canawati

Eradication of urinary tract infection following spinal cord injury

$K B$ Waites, $K C$ Canupp, $M J$ DeVivo

Persistent hypercoagulation associated with heterotopic ossification in patients

with spinal cord injury long after injury has occurred

A Perkash, $G$ Sullivan, L Toth, L H Bradleigh, $S$ H Linder, I Perkash

Intravenous disodium etidronate therapy in spinal cord injury patients with

heterotopic ossification

K Banovac, F Gonzalez, N Wade, J J Bowker

MRI evaluation of fusion mass incorporation after anterior cervical bony

fusions: preliminary findings

$T J$ Albert, D Lamb, M R Piazza, A E Flanders, $R$ A Balderston, J M Cotler

Intracavernous papaverine for impotence in spinal cord injured patients

$V$ K Kapoor, A S Chahal, S P Jyoti, Y J Mundkur, S V Kotwal, V K Mehta

Spinal dural arteriovenous fistula adjacent to a spinal neurofibroma $-\mathbf{a}$

misleading coexistence. Case report

I H Tekkök, B Açıkgöz, T Özgen, B Önol

Amarjit Singh Chahal, Medallist of the International Society of Paraplegia

1993

Meetings and Notices

The effectiveness of vibratory stimulation in anejaculatory men with spinal

cord injury. Review article

$H$ Beckerman, $J$ Becher, $G J$ Lankhorst

Complications and costs of management of acute spinal cord injury

$C H$ Tator, E G Duncan, VE Edmonds, L I Lapczak, D F Andrews

Relief of spasticity in SCI men and women using rectal probe

electrostimulation

L S Halstead, SW J Seager, J M Houston, KWhitesell, M Dennis, P W Nance

Chronic pain in the spinal cord injured: statistical approach and

pharmacological treatment

P Fenollosa, J Pallares, J Cervera, F Pelegrin, V Inigo, M Giner, V Forner

Effects of induced hypothermia on somatosensory evoked potentials in patients

with chronic spinal cord injury

$K C$ Hayes, J T C Hsieh, P J Potter, D L Wolfe, G A Delaney, A R Blight

Creatinine, calcium, citrate and acid-base in spinal cord injured patients

$R G$ Burr, C Chem, I Nuseibeh

Atypical syndromes caudal to the injury site in patients following spinal cord

injury. A clinical, neurophysiological and MRI study

L Tosi, C Righetti, G Terrini, G Zanette

Meetings and Notices 
Prevention of spinal cord injuries in an Australian study (New South Wales)

J D Yeo

Functional electrical stimulation (FES): muscle histochemical analysis

$J M D$ Greve, R Muszkat, B Schmidt, J Chiovatto, TE P Barros,

$L R$ Batisttella

Sexual function in spinal cord injury men. I. Assessing sexual capability

F J Courtois, K F Charvier, A Leriche, D P Raymond

Simplified and objective assessment of spermatogenesis in spinal cord injured men by flow cytometry analysis

I H Hirsch, D Kulp-Hugues, J Sedor, P McCue, M B Chancellor, W E Staas Factors contributing to the increased threat to life following spinal cord injury $J$ E Kiwerski

Extraspinal ependymoma presenting as a subcutaneous mass posterior to the sacrococcygeal region. Case report

$R$ Inceoğlu, F Özer, N Pamir, $S$ Küllü

Synovial cyst of dens causing spinal cord compression. Case report

W Choe, I Walot, C Schlesinger, I Chambi, F Lin

Meetings and Notices

808

Cumulative Contents

811

Indexes 